\title{
Lesson Learned From an In Situ Tube Thoracostomy in Postoperative Congenital Diaphragmatic Hernia Repair: Even an Open Pneumothorax Can Be Catastrophic
}

\author{
Postoperatif Konjenital Diyafragmatik Herni Onarımında In Situ Tüp Torakostomiden Alınan \\ Ders: Açık Bir Pnömotoraks Bile Katastrof Olabilir
}

\author{
(D) Prateek Arora1, (D) Habib Md Reazaul Karim ${ }^{1}$, (D) Subrata Kumar Singha1, (D) Kartik Basumatary1, (D) Nitin Kumar Borkar2 \\ ${ }^{1}$ All India Institute of Medical Sciences, Department of Anaesthesiology and Critical Care, Raipur, India \\ ${ }^{2}$ All India Institute of Medical Sciences, Department of Paediatric Surgery, Raipur, India
}

\section{Abstract}

Over the last few decades, the perioperative management of congenital diaphragmatic hernia $(\mathrm{CDH})$ has improved, yet, the management is challenging. Complications are common, and pleural complications like pneumothorax and effusion after open $\mathrm{CDH}$ repair are still a concern. Tube thoracostomy is often inserted to reduce postoperative pleural complications. However, tube thoracostomy, although having benefits and thought to be innocuous, may lead to life-threatening complications like tension pneumothorax. The present case report highlights an unusual scenario of acute respiratory failure with near cardiac arrest in the immediate postoperative period where the cause of the catastrophe was open pneumothorax rather than the tension one. The possible phenomena behind the said cause are described.

Keywords: Congenital diaphragmatic hernia, pneumothorax, cardiac arrest, patient safety

\section{Öz}

Son birkaç on yılda, konjenital diyafragmatik herninin (KDH) perioperatif yönetimi gelişmiştir, ancak yönetimi halen zordur. Komplikasyonları yaygındır ve açık $\mathrm{KDH}$ onarımından sonra pnömotoraks ve efüzyon gibi plevral komplikasyonların gelişmesi halen bir sorun oluşturmaktadır. Tüp torakostomi genellikle postoperatif plevral komplikasyonları azaltmak için yerleştirilir. Ancak tüp torakostomi, faydaları olmasına ve zararsız olduğu düşünülmesine rağmen, tansiyon pnömotoraks gibi yaşamı tehdit eden komplikasyonlara yol açabilir. Bu olgu raporu, katastrofun nedeninin tansiyondan ziyade açık pnömotoraks olduğu postoperatif dönemde hemen hemen kalp durması ile birlikte akut solunum yetmezliğinin alışımadık bir senaryosunu vurgulamaktadır. Söz konusu nedenin arkasındaki olası fenomen açıklanmaktadır.

Anahtar Kelimeler: Konjenital diyafragmatik herni, pnömotoraks, kardiyak arest, hasta güvenliği

\section{Introduction}

Management of congenital diaphragmatic hernia $(\mathrm{CDH})$ is still a challenge with reasonably higher perioperative mortality. ${ }^{1}$ Pleural complications like pneumothorax and effusion are common after open $\mathrm{CDH}$ repair. Studies have shown to reduce these complications from $28 \%$ to $10 \%$ with the placement of tube thoracostomy after surgery. Tube thoracostomy also reduces postoperative ventilation time and does not cause a delay in extubation. ${ }^{2}$ However, tube thoracostomy, although having benefits and thought to be safe, may lead to life- threatening complications like tension pneumothorax. We present a unique case of acute respiratory failure with near cardiac arrest in the immediate postoperative period where the cause of the catastrophe was open pneumothorax.

\section{Case Report}

A one-month-old male baby, weighing $2.6 \mathrm{~kg}$, born by cesarean delivery at term, was referred to our institute with a chief complaint of respiratory distress with a diagnosis

Yazışma Adresi/Address for Correspondence: Habib Md Reazaul Karim, All India Institute of Medical Sciences, Department of Anaesthesiology and Critical Care, Raipur, India E-posta: drhabibkarim@gmail.com ORCID ID: orcid.org/0000-0002-6632-0491

Geliş Tarihi/Received: 15.10.2019 Kabul Tarihi/Accepted: 16.02.2020

-Telif Hakkı 2020 Çocuk Acil Tıp ve Yoğun Bakım Derneği

Çocuk Acil ve Yoğun Bakım Dergisi, Galenos Yayınevi tarafından yayınlanmıştır. 
of congenital heart disease. On the $7^{\text {th }}$ day of life, the baby developed respiratory distress, refusal to feed, and bluish discoloration of the face. A diagnosis of $\mathrm{CDH}$ was made, and the baby was started on bubble continuous positive airway pressure (CPAP) and Ryle's tube feeding. The baby had heart rate (HR) of $140 / \mathrm{min}$, blood pressure of $75 / 50 \mathrm{mmHg}$, and $\mathrm{SpO}_{2}$ of $94 \%$ on CPAP. A diminished air entry on the left side of the chest was noted.

With high-risk consent, the baby was taken up for surgery after initial stabilization with the American Society of Anesthesiologists physical class -IV and anesthesia management was done as per standard institute practice, sevoflurane based balanced anesthesia was used. An intercostal drain was placed on the operated side of the chest at the end of the surgery. The operation lasted for one hour, and the baby was reversed, extubated, and shifted to the post-anesthesia care unit (PACU) for observation. Immediately after extubation, the baby had proper rhythmic respiration without any signs and symptoms of respiratory depression or difficulty. Auscultation over the trachea indicated free airflow without any obstructive sounds, both during inspiration and expiration, and the baby was shifted to PACU after 5 minutes.

After 20 minutes in the PACU, the nursing officer observed falling $\mathrm{SpO}_{2}$ with peripheral cyanosis. The baby was immediately reintubated under the vision, and assisted positive pressure ventilation with a self-inflating bag with $100 \%$ was administered. However, $\mathrm{SpO}_{2}$ did not improve, and the baby developed bradycardia with an HR of $54 \mathrm{bpm}$. Atropine $0.2 \mathrm{mg}$ was injected intravenously, and assisted ventilation continued. Bilateral positive air-entry sounds were positive but of diminished intensity. The endotracheal tube position was doubted, and the senior anesthesiologist re-intubated the baby yet with no immediate improvement. The HR further declined to below 40/min; immediately, chest compression was initiated along with injection epinephrine administration.

At this point, an observation was made that the thoracostomy tube was displaced up from the water seal. A suction catheter was then attached to the displaced end, and the displaced end was replaced correctly in the water seal. After the $\mathrm{SpO}_{2}$ and HR gradually improved, and the baby was placed on mechanical ventilation and shifted out to neonatal ICU for further management. The pre and postoperative $X$-ray is shown in Figure 1, where postoperative X-ray shows thoracostomy tube in-situ with lung field expansion as compared to the preoperative one.

\section{Discussion}

$\mathrm{CDH}$ management emphasizes understanding of the changes in ventilation and respiratory physiology. There occurs a dynamic interplay between pulmonary hypoplasia and herniation of abdominal organs into the thorax, leading to raised airway pressure, preferential ventilation of the contralateral lung, mediastinal shift, physical compression on the heart and thickened pulmonary vasculature. Thoracic contents are reduced back to the abdomen, which in turn gives the lung adequate area for expansion and gas exchange. The patient responded to the intraoperative management without any adverse note, and therefore, was extubated. However, in the immediate postoperative period, the patients' condition deteriorated acutely after around 20 minutes. In the postoperative period, compliance and gas exchange can deteriorate, ${ }^{3}$ which can lead to desaturation. We thought that the patient went to acute respiratory failure due to incomplete reversal or inadequate exchange of gases; hence, intubated the patient and ventilated. Nevertheless, it was not helpful.

The use of the tube thoracostomy after CDH surgery is arguable. While some fear the possible increased risk of complication and rationalize non-placement of the tube to encourage the lung to enlarge gradually, displacing fluid and air $^{4,5}$ a retrospective analysis has failed to show increased risk instead reported significant benefit in terms of recovery. ${ }^{2}$

Pneumothorax has been found as a significant risk factor for mortality. ${ }^{6}$ Tube thoracostomy is indicated for the prevention and management of pneumothorax and often connected with a chest drainage system. Even during transportation, chest drain clamping is usually not advised due to the risk of tension pneumothorax development in the face of continuous air leak. ${ }^{7}$ Even though thought innocuous and preventive, it can lead to devastating complications, as cited above, if not maintained in a proper underwater seal. Drain open to the atmosphere can suck in air into the already compromised neonate hemithorax, thereby pushing the mediastinum to the opposite side and compromising both ventilation and cardiac output. Tension pneumothorax is considered as a reversible cause of cardiac arrest (advanced cardiac life support). It

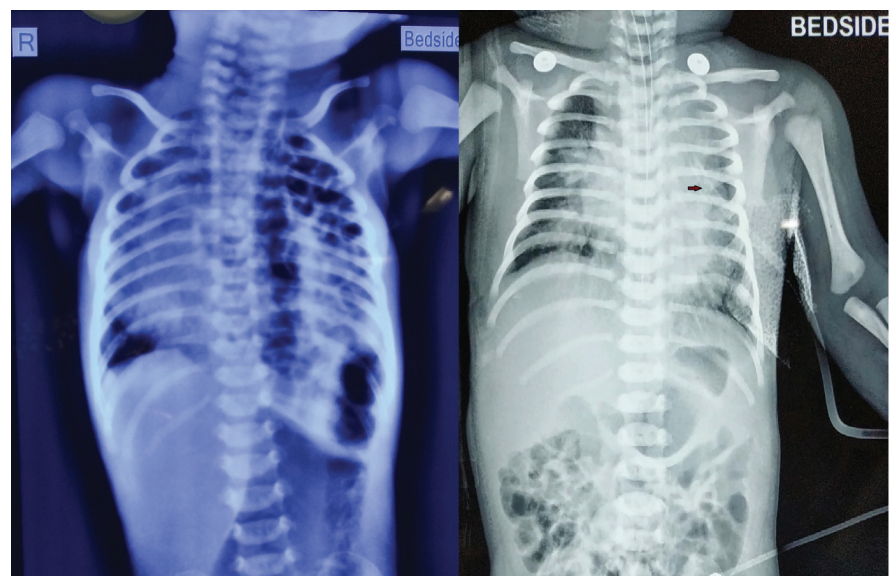

Figure 1. Preoperative and postoperative $X$-ray of the baby showing bowel content and in situ tube thoracostomy, respectively in the left hemithorax 
can even lead to failure of cardiopulmonary resuscitation if the air is not drained immediately. ${ }^{8}$ However, the probable pathophysiology in our patient appears not to be the tension pneumothorax, but an open pneumothorax. While the baby tried to take a breath, the air was sucked in through the least resistance path, i.e., thoracostomy tube. This changed the respiratory mechanics, and there was no gas exchange in the alveoli. Initially, with impaired ventilation, the baby tried compensatory hyperventilate, which lead to the more negative pressure generation, and more air was sucked in the hemithorax with tube thoracostomy in situ, ultimately leading to respiratory failure and subsequent near cardiac arrest. Even after intubation and ET in place, as the patient was not paralyzed, the negative pressure was still generated within the pleural cavity leading to air sucking, and this led to the persistence of the problem. This is supported by the fact that when the thoracostomy tube was partially closed, and it was positioned back to the underwater seal by one of the teammember, the oxygenation and hemodynamics improved, and the baby revived.

The other critical learning point is the implementation of structured postoperative patient handover. Technical and communication errors can negatively impact patient safety and outcome. A systematic review of the literature recommends standardized process through the use of checklists and protocols for better handover and outcome. ${ }^{9}$ Preparation of drains and tubes before shifting, information of these, and their care plan in the postoperative period needs to be be wellchecked and communicated. Inter-professional handover has also been suggested for safer patient transfer in the PACU. ${ }^{10}$ Better implementation of this point could have prevented the catastrophe in our patient.

To be noted that, bradycardia in pediatrics are mostly hypoxic (also known as primary bradycardia) and is better treated with Epinephrine rather than Atropine as per the pediatric advanced life support. However, in our case, the possibility of secondary bradycardia due to surgical injury was also one of the possibilities. Atropine is indicated in refractory primary bradycardia and secondary bradycardia. Although we administered Atropine as the first drug, Epinephrine was administered immediately as soon as we recognized that the baby was going to cardiac arrest.

\section{Conclusion}

The present case highlights the fact that special vigilance is required while shifting a postoperative $\mathrm{CDH}$ case with tube thoracostomy in-situ. Acute respiratory failure and cardiac arrest may even happen with open pneumothorax in such a situation. A multidisciplinary approach and management help in better decision making.

\section{Ethics}

Informed Consent: Informed and written consent were obtained from the parents of the baby for publication.

Peer-review: Internally peer-reviewed.

\section{Authorship Contributions}

Surgical and Medical Practices: P.A., H.M.R.K., S.K.S., K.B., N.K.B., Concept: P.A., H.M.R.K., S.K.S., K.B., N.K.B., Design: P.A., H.M.R.K., S.K.S., K.B., N.K.B., Analysis or Interpretation: P.A., H.M.R.K., Literature Search: P.A., H.M.R.K., S.K.S., K.B., N.K.B.

Conflict of Interest: No conflict of interest was declared by the authors.

Financial Disclosure: The authors declared that this study received no financial support.

\section{References}

1. Aihole JS, Gowdra A, Javaregowda D, Jadhav V, Babu MN, et al. A clinical study on congenital diaphragmatic hernia in neonates: Our institutional experience. J Indian Assoc Pediatr Surg. 2018;23:1319.

2. Schlager A, Arps K, Siddharthan R, Clifton MS. Tube thoracostomy at the time of congenital diaphragmatic hernia repair: reassessing the risks and benefits. J Laparoendosc Adv Surg Tech A. 2017;27:311 7.

3. Quinney $\mathrm{M}$, Wellesley $\mathrm{H}$. Anaesthetic management of patients with a congenital diaphragmatic hernia. BJA Educ. 2018;18:95-101.

4. Wung JT, Sahni R, Moffitt ST, Lipsitz E, Stolar CJ. Congenital diaphragmatic hernia: survival treated with very delayed surgery, spontaneous respiration, and no chest tube. J Pediatr Surg. 1995;30:406-9.

5. Kotecha S, Barbato A, Bush A, Claus F, Davenport F, et al. Congenital diaphragmatic hernia. Eur Respir J. 2012;39:820-9.

6. Han S, Lee S, Son J, Seo JM, Lee SK. Pneumothorax is a significant risk factor for mortality in congenital diaphragmatic hernia: A single center experience. Adv Pediatr Surg. 2018;24:68-75.

7. The Royal Children's Hospital Melbourne. Clinical Guideline (Nursing): Chest drain management. 2016 Feb . Last Accessed Date: 22.03.2019. Available from https://www.rch.org.au/rchcpg/ hospital_clinical_guideline_index/Chest_Drain_Management/

8. Buschmann CT, Tsokos M, Kleber C. Tension pneumothorax in unsuccessful cardiopulmonary resuscitation. Rom J Leg Med. 2014;22:221-3.

9. Segall N, Bonifacio AS, Schroeder RA, Barbeito A, Rogers D, et al. Can we make postoperative patient handovers safer? A systematic review of the literature. Anesth Analg. 2012;115:102-15.

10. Redley B, Bucknall TK, Evans S, Botti M. Inter-professional clinical handover in post-anaesthetic care units: tools to improve quality and safety. Int J Qual Health Care. 2016;28:573-9. 